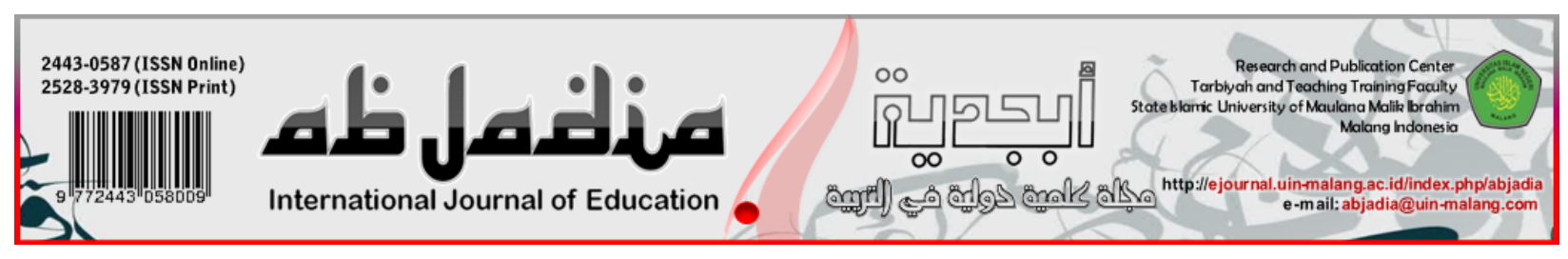

\title{
PROBLEMS ON INTERNATIONAL STUDENTS' PARAGRAPHS: A CASE STUDY AT UIN MAULANA MALIK IBRAHIM MALANG
}

\author{
Mohamad Zubad Nurul Yaqin \\ Universitas Islam Negeri Maulana Malik Ibrahim Malang, Indonesia
}

\begin{abstract}
Article History:
Received : 2021-11-30

Revised : 2021-12-01

Accepted : 2021-12-08

Published : 2021-12-26
\end{abstract}

\section{Keywords:}

Problems, International Students, Paragraph

*Correspondence Address:

zubad@pba.uin-malang.ac.id

\begin{abstract}
Ideas within student's scientific works must meet scientific conditions, one of which is written in a good and correct paragraph. Ironically, international students at UIN Maulana Malik Ibrahim Malang still make some mistakes upon writing papers even though they have been equipped with Indonesian language competence since the first semester. The current study aims to identify the problems on international students' paragraphs, to find their factors, and to spot alternative solutions. It employed a qualitative approach with a text analysis or discourse analysis. The data were the in the form of linguistic practices within students' papers. They were collected, classified, and analyzed according to the research focus. Three kinds of issues were found in the papers of international students at UIN Maliki Malang: not meeting the elements of cohesion and coherence, incomplete paragraph development, and unsequential paragraph development. Each form of the error supported one another.
\end{abstract}

\section{C) Introduction}

The language used in the scientific work is supposed to fulfill the standard language, which is good and proper according to the language rules. It should follow the requirements to establish an effective communication, that the intention of the writer is well delivered to the reader. Or, a communication is perceived to be effective once common understanding between the writer and the reader is achieved. In the context of scientific writing, every idea or concept that the author has is delivered in sentences to form paragraphs. The paragraphs must meet scientific requirements. The sentences must be effective, and the paragraph should be well-arranged.

As intellectuals, students are required to be capable of writing scientific papers. Therefore, they should master the applicable writing rules, including those of paragraph writing. This is the requirement to meet so that they can write properly and correctly. The international students of UIN Maulana Malik Ibrahim Malang are equipped with competencies to support the process of writing scientific papers. In the first semester, they are commonly required to take Indonesian language courses which focus on grammar, vocabulary enrichment, and speaking and writing for academic purposes. The materials cover proper and correct paragraph writings. Ironically, even though they are equipped with the competencies, they often make errors paragraph upon writing 
scientific works. Therefore, the current research is specifically intended to address the issues.

This study focuses on identifying the forms of errors in paragraphs within the papers of international students at UIN Maulana Malik Ibrahim Malang. It aims to attain an overview, clarification, and explanation of the forms of errors in the paragraph. Specifically, it aims to find out the causative factors of the errors which is in the end followed with various alternative solutions.

Theoretically, this research is expected to provide substantial contributions to the development of linguistic theory, especially those related to the theory of paragraph writing. Practically, this research is expected to provide insight and raise awareness among the readers, especially international students, that writing paragraphs for scientific works is not easy. For educators, especially lecturers, this research is expected to be used as a reference upon learning a paragraph.

This research is based on two assumption, those related to the research object and process. The objects of this research are papers written in Indonesian by international students at UIN Malang. The papers should obviously be written according to the applicable rules, including those of paragraph writing because they are equipped with competencies through Indonesian language courses which focus on academic writing. Besides, this research is natural and authentic. Therefore, it employs a qualitative approach with a text analysis method. The data are collected through documentation on the papers of international students at UIN Maliki Malang. The data are analyzed inductively based on the data analysis, research findings, and research validity.

Paragraph is a set of sentences which explains about a particular topic or idea (Arifin, 2006: 125). It begins with a new line (Sakri, 1992). Finoza (2007) views paragraph as a unit of language which contains several sentences. According to Nurul Yaqin (2011), a paragraph is a combination of several sentences that meet the elements of cohesion and coherence.

In a scientific paper, a good paragraph contains only one main idea followed by several explanatory ideas. The main idea is a topic developed into a paragraph, and it serves as a controller for the whole paragraph. Explanatory ideas serve to explain the main idea. The characteristics of the main idea are (1) presenting potential problems to elaborate further, (2) a single independent clause, (3) containing a clear meaning even though it is not connected with other sentences, and (4) complete without conjunctions and transition words. The characteristics of the explanatory sentence are (1) dependent clauses, unable to stand alone, (2) sometimes the meaning can only be understood when it is connected to another sentence, (3) generally containing conjunctions and transition words, and (4) containing details, examples, and other additional words that support the topic sentence.

In general, the characteristics of a paragraph are: consisting of several sentences, 
the development of ideas are originated from the main idea in the topic sentence, and the main idea is equipped with several explanatory ideas. The function of a paragraph is to express ideas in writing into a series of logically arranged sentences in a single unit, to mark the turn of new ideas for essays consisting of several paragraphs, to ease writers to organize ideas, and to help readers understand the ideas presented in the paragraphs.

A scientific work must also be united (cohesive) and interalated (coherent). Paragraph unity (cohesion) means that each paragraph contains only one main idea. Although it consists of several sentences, the whole sentence does not deviate from the main idea. Coherence refers to the interaltedness of a sentence with the others. They are built with logical thought relationships, so the structure and meaning are clear. It can be made by repetition of keywords or synonyms by using pronouns, arranging sentences in parallel, and using transition markers (connectors). In addition, we may also present the materials completely by using a fixed point of view (consistent), and arranging each idea in sequence.

Based on the location of the main idea, paragraph is divided into four, deductive, inductive, combined, and complete. Deductive paragraphs refers to those that begin with a main idea. The inductive ones refer to those whose main idea is at the end of the paragraph. A combined paragraph contains a main idea at the beginning and the end. The full paragraph contains equally important ideas within all sentences so that no particular sentence becomes the main idea. This paragraph is often found in the descriptive and narrative writings, especially in fiction.

Based on the idea development, a paragraph can be divided into argumentative, persuasive, descriptive, narrative, and expository. An argumentative paragraph conveys an idea about particular problem to convince the readers. The idea is accompanied by logical and objective arguments. This type of paragraph is often used in the scientific essays. A persuasive paragraph refers to the paragraph containing a discussion of a problem to persuade, attract, invite, and convince the readers to follow what the author wants. Descriptive paragraph describes an object or event objectively so that it clearly shows the readers about the object or event. This paragraph is usually used in the literary works and biographies. Expository paragraph describes a certain fact or event to broaden the reader's insight or knowledge. Generally, this paragraph describes how to make something, how to use something, and so on. Narrative paragraph tells a series of events or circumstances associated with certain periods through storytelling. This kind of paragraph is generally used in the essays, biographies, novels, short stories, and romances.

Based on the position and function, it can be divided into opening paragraphs, connecting paragraphs, and closing paragraphs. The opening paragraph serves as an introduction to the problem. It functions to attract the attention of the reader and to prepare the mind of the readers to know the entire contents of the essay. Paragraph connector or developer aims to develop the main problems formulated previously. This 
section generally includes examples, illustrations, etc. The closing paragraph is the paragraph that ends the essay. It contains the conclusions presented in the connecting paragraph. Besides, it can also contain a reaffirmation of the author's main problems that have been described in the connecting paragraph.

There are several techniques that can be used by a writer in developing paragraphs with the following description: 1) Natural technique, which refers to the paragraph development technique based on the order of space and time (chronological). The information is delivered coherently to help facilitate readers' understanding; 2) Climax technique, a paragraph that starts with the less important information to the highly important one. In contrast, the anti-climax technique begins with the very important information to the less important one; 3) General to specific techniques which refers to the paragraph development technique that begins with the general main idea followed by the more specific supporting ideas. In contrast, it can be from specific information to the general one, called specific to general technique; 4) Comparison and contrast techniques, which clarifies the main idea by comparing and contrasting it. The author shows the similarities and differences between two things; 5) Analogy technique, which is made by comparing or equating an object that has been known with the less-known one, yet the goal is to explain the less-known; 6) Technique of examples (generalization), which develops paragraphs by presenting concrete objects (examples) that can provide evidence (explanations) more generally to the reader; 7) Cause-effect technique, which makes the cause as the main idea, and the effects are used as explanatory ideas. It may happen the other around, which is called "effect-cause technique"; 8) Broad definition technique, a paragraph development technique that provides an explanation of particular object with a few sentences to explain the definition; 9) Classification technique, which is performed by grouping similar things to clarify the main sentence.

\section{[Q] Method}

Errors in the paper of international students of UIN Maliki Malang were observed and analyzed in depth. As a corpus of data, the errors were described according to the aspects formulated in the research focus. Furthermore, the description results were analyzed by referring to the theoretical framework that has been set. With the illustration, this study employed a qualitative approach as: (1) it emphasizes meaning, context, emic prestige, and the work process accentuated cycles rather than linearity; (2) data collection and analysis were made intensively and continuously; and (3) the research concerned more on the depth and understanding than the coverage. Besides, this research used a text analysis or discourse analysis approach because the discussion referred to texts. The data were in the form of linguistic practices, written communication (papers of international students at UIN Maliki Malang), in which the errors were found.

This study exploited main and supporting instruments. The main instrument was the researcher himself while the supporting ones were the data collection instruments, 
data analysis instruments, complementary data analysis instruments, research instrument grids, selected data charts, and selected data alignment charts, and temporary interpretations based on the research problems and objectives.

In principle, each datum was collected, classified, and analyzed according to the research focus. To achieve the research focus, it adopted data collection, classification, and analysis, by which the error patterns were identified.

\section{ز⿱一兀) Result and Discussion}

In general, there found three forms of errors within the paragraphs of international students at UIN Maulana Malik Ibrahim Malang: 1) the paragraph is not cohesive and coherent; 2) the paragraph is not completely developed, and 3) the paragraph is not coherently developed. Each form of error is interrelated with one another. In order to obtain more thorough understanding, these errors are specifically explained as follows.

\section{The paragraph is not cohesive and coherent}

Some paragraphs in the papers of international students at UIN Maulana Malik Ibrahim Malang are not cohesive. The following are the examples:

One of the efforts made by teachers to improve the quality of education is developing methods and strategies in teaching. The effort is made by creating interactive media that can stimulate the interest and increase the enthusiasm of students in learning. The presentation by using multimedia can be received by the senses of sight and hearing, closer to the original form in the real world. Interactive multimedia refers to the application all existing multimedia elements. (M1-K.Pr1)

The above paragraph (M1-K.Pr1) contains two main ideas, which discuss about: "the efforts of teachers to improve the quality of education" and "the multimedia used". The discussion about multimedia is supposed to be provided in the next paragraph. Similar errors also occur in the following paragraph.

According to the Indonesian dictionary, electronics are tools made based on the working principle of electronics. In this case, the learning is designed in an electronic model, which is an electronic comic. Usually, a comic is written in papers as the media, in contrast to electronic comics designed by using electronic media. (M2K.Pr1)

The paragraph (M2-K.Pr1) also contains two main ideas, discussing " about the definition of electronics according to the Indonesian dictionary" and "about the comic". Similar error is also found in the following paragraph.

Electronics is the study of weak current electrical devices operated by controlling the current of electrons or electrically charged particles in a device, such as a computer, electronic equipment, semiconductors, thermopoles, and so on. Electronic devices can 
produce sounds, send messages, show pictures, measure, remember, and calculate them. Story is a speech that describes how something happened. (M2-K.Pr2)

The paragraph (M2-K.Pr2) consists of two main ideas. The first idea is about the definition of electronics in general while the second is about the definition of a story.

The three examples of paragraphs show that the paragraphs in the papers of international students are not cohesive. It also strengthens the research by Lestari (2016) which reveals that cohesion has the highest rate in the discourse analysis on the daily editorials of Kompas published in April 2018.

The next analysis is about coherence. Some papers contain paragraphs which are not coherent between one paragraph to another and inter paragraph (between one sentence to another in a single paragraph).

\section{Inter Paragraph Coherence}

The rapid development of science and technology has its own impact on various lives, one of which is in the field of education. In Islam, we are required to be knowledgeable, as affirmed by Allah in his word. (M3-K.Pr1)

The above example shows that the first sentence and the second sentence are not coherent. The first sentence discusses about knowledge and technology while the second sentence explains about science and knowledge in terms of religion. Similar error is found in the following paragraph.

In the development of life as individuals or members of society, humans need guidance. The most merciful God sent prophets and messengers to them to practice the guidance. Prophet means the one who gets information... (M3-K.Pr2)

The paragraph shows that the second sentence is not coherent with the first one. The first sentence is supposed to explain about the ones who can provide guidance. And, the second sentence can discuss about the guidance revealed by God.

\section{Coherence between One Paragraph and Another}

The following are the examples of paragraphs which are not coherent with one another.

to master the technology, one can learn from formal education. Education is now necessary for every human being. With knowledge, one will have the ability. (M4-K.Pr1)

A reform in education influence the attitudes, behavior, and values of individuals and society... (M4-K.Pr2)

The above paragraphs are not coherent with one another. The first paragraph discusses about formal education as a way to master science and technology while the second one presents about the update in education. The first paragraph should ideally 
explain about the areas of reformation, one of which is related to that in the field of education.

Learning process is basically a communication process between educators and students. As a facilitator, the teacher acts as a guide, leader, and the one can make an environment as a source of learning. (M5-K.Pr1)

The department of Arabic Language Education at UIN Maliki Malang, in the process of learning information and communication technology, especially in learning computer hardware, still adopts the lecture method, ... (M5-K.Pr2)

The paragraphs above are incoherent with one another. The first paragraph discusses about learning process while the second one explains about the learning process at the department of Arabic Language Education at UIN Maliki Malang. The previous paragraph should ideally discuss about the learning process at various levels of education. Then, the next paragraph specifically discusses about the learning process in the department of Arabic Language Education at UIN Maliki Malang.

\section{Incomplete Idea Development}

The papers of international students at UIN Maulana Malik Ibrahim Malang also contain paragraphs which are incomplete in their development. The examples are as follows:

The professional multimedia authoring software, Adobe Flash, which is used to create the content of Adobe Engagement Platform, such as web applications, games, movies, and mobile phone content. (M6-K.Pr1)

The above example of paragraph is incomplete because it does not explain the use of the application on the web, games, movies, and mobile phone content. Similar error can also be found in the following paragraph.

The design process generally considers the aspects of function, aesthetics, and others, whose data are usually obtained from researches, ideas, brainstorming, or from pre-existing designs. (M7-K.Pr1)

The example of the paragraph above is incomplete because it does not explain the intended aspects.

\section{Uncoordinated Idea Development}

The papers written by international students at UIN Maulana Malik Ibrahim Malang also contain the following errors.

According to Ilham Moleong, learning model has three positions, which are extrinsic motivation as a tool for generating learning motivation, learning strategies, and adherence to the personal differences of students, and learning models as a means to achieve goals. Learning models can increase the absorption of students and provide a direct impact on achieving goals. (M8-K.Pr1) 
Learning model is the method adopted to implement the plans prepared in the real activities so that the objectives that have been prepared are optimally achieved. (M8-K.Pr2)]

The example of the paragraph is not coherent. The first paragraph is supposed to explain about the definition of learning model, then followed with the position of the learning model. Similar error is also found in the following paragraph.

At first, this network was called DARPA internet, yet it was then called "internet". At the initial use, internet access was only limited to the military, Ministry of Defense, and universities. However, after the opening of MAYARA USENET and BITNET, internet can be accessed through computer facilities. In 1990, the internet experienced a very rapid development. At this time, WIDE WEB began to be developed by CERN. (M9-K.Pr1)

The understanding of internet. The term internet comes from the Latin "intern" which means "between". Literally, internet means an intermediate network or link. According to the term, it is a connection between different types of computers and networks of different worlds. The operating system and its applications. (M9K.Pr2)

The two paragraphs are not coherent. The first paragraph should explain the definition of the internet, then followed by its development.

The discussion concluded five kinds of language errors in the paragraphs of international students' papers at UIN Maliki Malang. They are not cohesive, incoherent, less developed, incomplete, and incoherent with one another. According to Wijayanti (in Deswalantri, 2016: 33), a good paragraph must meet the elements of cohesion, unity, completeness, and coherence.

a. Coherence, all sentences within the paragraph are compact, interrelated, and supporting the main idea. To be coherent, connectors are sometimes needed between one sentence to another.

b. Unity or cohesion, all sentences that build a paragraph together state a certain thing and theme. Unity should not be interpreted as merely containing a single topic. It may explain several things, but it must support the main idea.

c. Completeness in development, it refers to the complete or finished paragraph, not the hang-on one. To develop a complete paragraph, a development technique is required (contradictory, comparison, analogy, example, cause-effect-definition, and classification).

d. Presented in sequence, the information is written according to the writing style. Common patterns which can be used to explain the main idea of a paragraph are: general to specific, specific to general, whole to parts, question to answer, effect to cause, and cause to effect. 
The common mistakes in the papers of international students at UIN Maliki Malang are induced by the limited knowledge of students about the rules of the Indonesian language, and the tendency to only perform imitation (plagiarism), only presenting other people's ideas or sentences without citing the source (Jalal, 2012:92 in Sudigdo, 2007).

\section{道 Conclusion}

This study concludes that the international students at UIN Maliki Malang should ideally avoid any plagiarism once writing scientific works. In addition, they need to increase their ability to make a coherent, united, sequenced paragraph. Therefore, they need to understand the requirements of paragraph writing. Future research can make the most of the current result to broaden the insight of the researchers.

\section{Bibliography}

Arikunto, Suharsimi. 2002. Prosedur Penelitian Suatu Pendekatan Praktik. Jakarta: Rineka Cipta.

Azhari, S. and Suyitno, I. 2000. Cermat Berbahasa Indonesia. Malang: Malangkucecwara.

Basuki, I.A. et al. 1995. Bahasa Indonesia Ilmiah. Malang: Institut Keguruan dan Ilmu Pendidikan Malang.

Brown, G. and Yule, G. 1996. Analisis Wacana, Translated by I. Sutikno. 1996. Jakarta: PT Gramedia Pustaka Utama.

Darma, Yoce Aliah. 2013. Analisis Wacana Kritis. Bandung: Yrama Widya. Bandung: PT Revika Aditama.

Darma, Yoce Aliah. 2014. Analisis Wacana Kritis dalam Multiperspektif. Bandung: Refika Aditama.

Djajasudarma, T.F. 2006. Wacana: Pemahaman dan Hubungan Antarunsur.

Eriyanto. 2017. Analisis Wacana: Pengantar Analisis Teks Media. Yogyakarta: LKis.

Eriyanto. 2002. Analisis Framing: Konstruksi, Ideologi, dan Politik Media. Yogyakarta: LKis

Fairclough, Norman. 20013. Langue and Power: Relasi Bahasa, Kekuasaan, dan Pembebasan. Diterjemahkan oleh Agung Prihantoro dan Faud Arif Furdiyantoro. 2007. Yogyakarta: Pustaka Pelajar.

Moeleong, L.J. 2006. Metode Penelitian Kualitatif. Bandung: PT Remaja Rosdakarya.

Nurul Yaqin, Mohamad Zubad. 2011. Bahasa Indonesia Keilmuan. Malang: UIN-Malang Press. 
Nurul Yaqin, Mohamad Zubad. 2009. Alquran sebagai media pembelajaran Bahasa Indonesia. Malang: UIN-Malang Press.

Schiffrin, D. 1994. Ancangan Kajian Wacana, Translated by Abdul Syukur Ibrahim, Ed. 2007. Yogyakarta: Pustaka Pelajar.

Van Dijk, T.A . 1985. Handbook of Discourse Analysis, Vol. 2 Dimnesion of Discourse. New York: Academic Press.

Van Dijk, T.A . 1985. Handbook of Discourse Analysis, Vol. 3 Dimnesion of Discourse. New York: Academic Press.

Zaimar, Okke Kusuma Sumantri dan Ayu Basoaki Harahap. 2011. Telaah Wacana. Depok: Komodo Books.

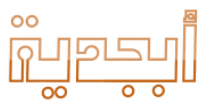

